Alumni Association dedicated its 2014 annual meeting as an "Homage à Taoufik Agoumy" on 6 December 2014 at the Bibliothèque Nationale du Royaume du Maroc. \&

DOI:10.1017/rms.2016.31

James A. Miller

Moroccan American Commission for Educational and Cultural Exchange (MACECE)

\title{
Patricia Crone
}

\section{5-2015}

Since her death on July 11, 2015, several obituaries for Patricia Crone have been written, outlining her biography and attempting to summarize her scholarly achievements. As far as I can see, all these obituaries avoided recalling her most striking features, those immediately noticeable when first meeting her: her beauty, her lightning-quick intelligence, her effortless wit. One feels a certain pudeur in expanding about such natural gifts, especially when still mourning her departure. It is easier to talk about her other enviable qualities, those more amenable to some elaboration.

My first encounter with Patricia Crone happened through her generosity, when, as a graduate student, I unexpectedly received from her some material that drastically changed the course of my work. Grateful for the help and somewhat overawed by this already admired scholar, I lamely offered to reciprocate; to which she responded saying that she chose to forgo the wala ${ }^{c}$ al-ni ma. In the following years I came to know how significant were both wala ' and ni 'ma in her person.

Many have been the recipients of her help and support, which she gave generously and with true kindness, from the mentorship of young scholars to less conventional ni 'am, such as hopping on a plane on a moment's notice in order to stand by a student struggling with difficult health issues. Patricia had no patience for sloppiness, shallowness, slowness, ignorance, cowardice or intellectual conformism, and her penetrating observations and sharp remarks could be quite devastating. At times, her biting criticism and her non-conformism made her, as she knew well, the bête noire of many traditional scholars. But these same characteristics, topped with her unstinting generosity, created around her a wide circle of appreciative colleagues and loyal, loving friends. Her bluntness was never ego-driven, 
and her impatience always reflected a contagious, disinterested passion for knowing and understanding. It is no coincidence that this outspoken, original, and very independent mind easily entered collaborative efforts; four of her monographs were written jointly with other leading scholars.

Wala ', the patronage system of early Islam, was the topic of her doctoral dissertation (The Mawāli in the Umayyad Period, University of London, 1974), and she returned to the topic in later books (e.g. Slaves on Horses: The Revolution of the Islamic Polity [Cambridge University Press, 1980]). Beyond the specific case of the patronage system, Crone was intrigued by the historical continuity that connected the explosive revolution of early Islam with the world of late antiquity. She studied this continuity in many of her articles and books, up to her last magnum opus (The Nativist Prophets of Early Islamic Iran: Rural Revolt and Local Zoroastrianism [Cambridge University Press, 2012]). Although an excellent Arabist herself, she was first and foremost an historian who understood that Islam "cannot have been born by parthenogenesis," and who shunned the narrow view of much admired "purebred Arabist[s] to whom the pre-Islamic Near East is terra incognita." Analyzing the development of contemporary Islamic Studies, she pointed out "a general shift in the direction of research in Islamic studies, or indeed in the arts at large, after the first world war. All branches of the arts suffered from professionalization, or in other words: from the transfer of scholarship to universities, where standard syllabi, departmental divisions and academic career structures soon led to loss of depth and range alike" (Roman, Provincial and Islamic Law, Cambridge University Press, 1987, pp. 2-7)

The Institute for Advanced Study in Princeton, where she was appointed Professor in 1997, gave her the freedom to sidestep the professionalization and departmentalization of Islamic Studies in the universities. Among the countless professional conferences in which members of the academic world participate, the summer colloquia which Crone organized at the Institute stood out as particularly stimulating, interdisciplinary intellectual events: the topic was always examined from multiple angles in different chronological and geographic settings, as the participants, from various fields, shed light on different aspects of the topic. And typically, Crone did not look for academic stars, but for scholars interested in sharing and acquiring knowledge, regardless of seniority or fame.

The edifice of scholarship is made of both data and people. The research data, laboriously collected and patiently stacked, are inanimate objects: it is people who interpret them, people who inspire colleagues and students and animate the data with their enthusiasm, people who actually build the edifice of scholarship. Patricia Crone was a master builder. Her imposing scholarly 
edifice endures after her, just as the memory of her extraordinary personality and her astonishing intellectual force vividly remains with her colleagues and friends. $\$$

DOI:10.1017/rms.2016.65

Sarah Stroumsa The Hebrew University of Jerusalem

\section{James W. Hudson \\ 1930-2015}

James W. Hudson, professor emeritus at Morgan State University, passed away on 28 August 2015, at his home in Baltimore, Maryland, after a long illness. James' father Donald, himself the son of missionaries and born in Japan, passed on to Jim a strong interest in international issues and a love of travel that helped shape his professional career and personal life.

Jim was born on 28 March 1930, in Carlinville, Illinois, and grew up in Evanston, outside of Chicago. He received his BA in geography from Haverford College in Pennsylvania in 1952 and his MS in geography from the University of Wisconsin in 1954.

After receiving his master's, Jim wanted a respite from school. Shortly after a conversation with his uncle (a physician who had provided medical treatment to bedouin in eastern Syria and taught at the American University of Beirut medical school), he applied for a teaching position at the International College in Beirut, Lebanon. He taught English there from 1954 to 1956 and traveled throughout the region, including Syria, Jordan, and Palestine. It was during this time in Beirut that Jim developed a lifelong interest in the Middle East.

In 1956, Jim returned to the U.S. and earned his PhD in geography from the University of Chicago. After two years teaching geography at Central Michigan University in Mount Pleasant, he decided to return to the Middle East. He taught geography at the American University of Beirut for the next six years.

Jim returned to the States and in 1970 took a position with Morgan State University as a professor of geography. He remained at the school until his retirement in 1992. While at Morgan State, Jim established the master of arts program in international studies. He was a member of the Association of American Geographers and a founding member of the Sudan Studies 